\title{
ODPŁYW RZEK W POLSCE W RÓŻNYCH FAZACH OSCYLACJI PÓŁNOCNOATLANTYCKIEJ
}

\author{
DARIUSZ WRZESIŃSKI \\ Zakład Hydrologii i Gospodarki Wodnej, Instytut Geografii Fizycznej i Kształtowania Środowiska \\ Przyrodniczego, Uniwersytet im. Adama Mickiewicza w Poznaniu
}

\begin{abstract}
Deviations of climatic elements from average levels, like those caused by changes in the atmospheric circulation, modify the conditions in which the river runoff forms. The river regime is controlled by both, precipitation and air temperature, whose magnitudes show a significant dependence on the intensity of zonal circulation. A simple indicator characterising the atmospheric circulation over the north Atlantic is the North Atlantic Oscillation Index (henceforth, NAO). The North Atlantic Oscillation is considered a very important climate-forming factor in Poland.

The analysis embraced monthly, seasonal and annual runoff of Polish rivers taking into consideration Hurrell's winter NAO index from the years 1951-2000. The analysed flow series came from 141 profiles located on 86 Polish rivers. The selected rivers are distributed evenly throughout Poland and represent a diversity of environmental conditions (Fig. 1).

The aim of the present research was to examine the extent to which the North Atlantic Oscillation affects the runoff of Polish rivers: its seasonal structure and spatial variability. Differences were calculated between the monthly, seasonal and annual runoff observed in the years with exceptionally high (NAODJFM > 2) and low (NAODJFM $<-2$ ) values of the winter NAO index and their statistical significance was determined. Also calculated were monthly, seasonal and annual deviations of runoff in the years with high NAODJFM indices from that in the years with their low values (assuming the runoff in the years with low NAODJFM indices to be $100 \%)$.

The research results have confirmed a strong effect of the North Atlantic Oscillation on the runoff volume of the Polish rivers. In the winter months - January, February and March, the most statistically significant positive relations can be observed on rivers in the north-east and north of the country. The river runoff in those regions in a positive NAO stage is then more than $200 \%$ higher than in a negative stage. In the spring months, in April hold for the runoff of rivers in north-eastern Poland and the middle parts of the Oder and Warta basins, and in May, rivers of almost the entire country with the exception of the east and south-east. In those areas streamflow in a negative NAO stage is more than $50 \%$ higher in a positive NAO stage. The obtained results show that the North Atlantic Oscillation has the greatest effect on streamflow in the winter-spring months, i.e. in the period when the most abundant water resources are being formed in Poland. Hence, in a positive NAO stage, one might expect a considerable buildup of the water resources in the winter months, mostly in the north-east, and their marked dwindling almost throughout the entire country in spring.
\end{abstract}

Keywords: North Atlantic Oscillation, river runoff, statistical significance of the difference ( $T$-test)

\section{WPROWADZENIE}

Prostym wskaźnikiem charakteryzującym cyrkulację atmosferyczną nad północnym Atlantykiem i wpływającym na warunki klimatyczne w Europie jest wskaźnik Oscylacji Północnoatlantyckiej (NAO). Ten makroskalowy typ cyrkulacji atmosfery również w Polsce odgrywa bardzo ważną, klimatotwórczą 
rolę (Marsz, Żmudzka 1999; Marsz 2001). Odchylenia elementów klimatycznych od wartości przeciętnych wywołane na przykład zmianami cyrkulacji atmosferycznej prowadzą do modyfikacji warunków kształtowania się odpływu rzecznego. Na reżim odpływu wpływają zarówno opady atmosferyczne, jak i temperatura powietrza, których wysokości wykazują istotne zależności od natężenia Oscylacji Północnoatlantyckiej. Stwierdzono silny wpływ tego typu cyrkulacji na wzrost temperatur w chłodnej porze roku (Kożuchowski, Degirmendžic 2002; Marsz, Styszyńska 2001; Niedźwiedź 2002; Przybylak i in. 2003) oraz warunki: radiacyjne, wilgotnościowe, radiacyjne (Bryś, Bryś 2002), opadowe (Styszyńska 2001; Wibig 2001), a także czas trwania i grubość pokrywy śnieżnej (Falarz 2007; Bednorz 2009). Coraz częściej obserwuje się także zainteresowanie hydrologów zagadnieniem wpływu NAO na odpływ rzek polskich. Powszechnie uznawany jest wpływ NAO na formowanie wezbrań roztopowych rzek Europy Środkowej (Kaczmarek 2002; 2003, Wrzesiński 2004, 2005). W pozytywnej fazie NAO zazwyczaj obserwuje się niższe wezbrania wiosenne niż w fazie negatywnej. Badania potwierdziły także wpływ NAO na przepływy Warty (Styszyńska 2002; Styszyńska, Tamulewicz 2004) oraz wykazały istnienie asynchronicznych zależności między zimowymi indeksami NAO a przepływami niektórych rzek karpackich i Wisły (Limanówka i in. 2002; Pociask-Karteczka i in. 2002). Analizę zmian okresów hydrologicznych i cech reżimu odpływu rzek europejskich w różnych fazach NAO przeprowadził Wrzesiński (2004, 2005, 2007, 2008b). Na rzekach Europy Środkowej zazwyczaj nie zmienia się sekwencja okresów hydrologicznych, natomiast ulega zmianie termin pojawiania, czas trwania oraz natężenie występującego $\mathrm{w}$ danym okresie zjawiska hydrologicznego. Wezbrania wiosenne w negatywnej fazie NAO są wyraźnie wyższe, późniejsze i krótsze, natomiast w dodatniej fazie NAO obserwuje się wcześniejszy termin rozpoczęcia okresu niżówkowego, wyższy odpływ niżówkowy, natomiast nieznacznej zmianie ulega czas trwania okresów niżówkowych. Wyniki badań Wrzesińskiego (2008a) potwierdziły silny wpływ Oscylacji Północnoatlantyckiej również na warunki formowania odpływu polskich rzek. Ze współczynników korelacji zimowego indeksu NAO z odpływami miesięcznymi i sezonowymi mamy, że obserwowane zależności wykazują duże czasowe i przestrzenne zróżnicowanie. Najsilniejszy wpływ intensywności Oscylacji Północnoatlantyckiej wywierany jest na odpływ w sezonie zimowym i wiosennym, przy czym zimą obserwuje się zazwyczaj dodatnie, a wiosną ujemne korelacje. W miesiącach zimowych, w styczniu i lutym, a także w marcu, najbardziej istotne statystycznie, dodatnie korelacje wykazuje odpływ rzek w północno-wschodniej i północnej części kraju. W miesiącach wiosennych istotne statystycznie ujemne korelacje w kwietniu dotyczą odpływu rzek północno-wschodniej Polski oraz środkowej części dorzecza Odry i Warty, a w maju większości rzek, z wyjątkiem położonych we wschodniej i południowo-wschodniej części kraju. W pozostałych miesiącach odpływ większości 
analizowanych rzek zazwyczaj nie wykazuje istotnych statystycznie zależności od NAO. Dominują jednak ujemne korelacje, jedynie w części wschodniej i północno-wschodniej kraju przeważają korelacje dodatnie. Zmiany warunków klimatycznych wywołanych między innymi zmiennym natężeniem Oscylacji Północnoatlantyckiej przyczyniają się także do destabilizacji cech reżimu odpływu rzek w Polsce (Wrzesiński 2009). Zmiany współczynników stabilności występowania najwyższych i najniższych odpływów miesięcznych w latach 1822-2005 rzeki Warty w profilu Poznań wyraźnie nawiązują do przebiegu wyróżnionych przez Marsza (1999) tak zwanych epok cyrkulacyjnych NAO. $\mathrm{W}$ czasie cieplejszych zim w pozytywnej fazie $\mathrm{NAO}_{\text {DJFM }}$ obserwuje się większą zmienność zasilania roztopowego i wcześniejsze kulminacje wezbrań, co prowadzi do zmniejszenia stabilności wystąpienia ich terminu. Natomiast słabszy jest wpływ zmian natężenia $\mathrm{NAO}_{\text {DJFM }}$ na stabilność fazy niżówek letnio-jesiennych.

Silne korelacje przepływu polskich rzek z zimowym indeksem NAO sprawiaja, że interesującym zagadnieniem staje się odpowiedź na pytanie, jak kształtuje się odpływ rzeczny, jego wysokość i sezonowość (zmiany w cyklu rocznym) w różnych fazach NAO.

\section{MATERIAŁY ŹRÓDŁOWE I METODY PRACY}

W analizie uwzględniono miesięczne, sezonowe i roczne odpływy 86 polskich rzek (141 serii pomiarowych) z lat 1951-2000 oraz zimowy indeks NAO Hurrella (Hurrell 1995, uaktualnienia: http://www.cgd.ucar.edu/cas/jhurrell/nao. stat.winter.html).

Wytypowane rzeki położone są równomiernie na terenie Polski. Reprezentują zróżnicowane warunki środowiskowe i quasi-naturalne warunki odpływu (ryc. 1).

Zmiany warunków odpływu rzek w Polsce w różnych fazach NAO i ich przestrzenne zróżnicowanie określono na podstawie różnic wysokości odpływu w analizowanych fazach NAO względem siebie. W pracy obliczono różnice miesięcznych, sezonowych i rocznych wysokości odpływu rzek między latami o wysokich ( $\mathrm{NAO}_{\text {DJFM }}>2,0$; pozytywna, dodatnia faza $\left.\mathrm{NAO}\right)$ i niskich $\left(\mathrm{NAO}_{\mathrm{DJFM}}\right.$ $<-2,0$; negatywna, ujemna faza NAO) wartościach zimowego indeksu NAO. Liczby te w przybliżeniu odpowiadają pierwszemu i trzeciemu kwartylowi z całego zbioru wskaźnika $\mathrm{NAO}_{\text {DJFM }}$ w latach 1951-2000. Następnie zbadano istotność statystyczną tych różnic testem $T$ dla prób niezależnych. Każdorazowo testowano hipotezę $\mathrm{H}_{0}: \mu_{1}=\mu_{2}$ o równości wartości oczekiwanych przeciwko $H_{1}: \mu_{1}$ $\neq \mu_{2}$. Odrzucenie hipotezy pozwala wnioskować o istotnych różnicach średnich wartości odpływów rzecznych obserwowanych w różnych fazach NAO $\mathrm{DJFM}_{\text {M }}$. Statystyka $T$ ma rozkład Studenta, przy $n_{1}+n_{2}-2$ stopniach swobody: 


$$
T=\frac{\overline{X_{1}}-\overline{X_{2}}}{S_{\overline{X_{1}}-\overline{X_{2}}}}
$$

gdzie $S_{\overline{X_{1}}-\overline{X_{2}}}$ wynosi

$$
S_{\overline{X_{1}}-\overline{X_{2}}}=\sqrt{\frac{\left(n_{1}-1\right) \cdot S_{1}^{2}+\left(n_{2}-1\right) \cdot S_{2}^{2}}{n_{1}+n_{2}-2} \cdot\left(\frac{1}{n_{1}}+\frac{1}{n_{2}}\right)}
$$

gdzie $n_{1}, n_{2}$ - liczebność prób, $S_{1}^{2}, S_{2}^{2}$ - wariancje próbowe, $\overline{X_{1}}-\overline{X_{2}}-$ średnie z próby.

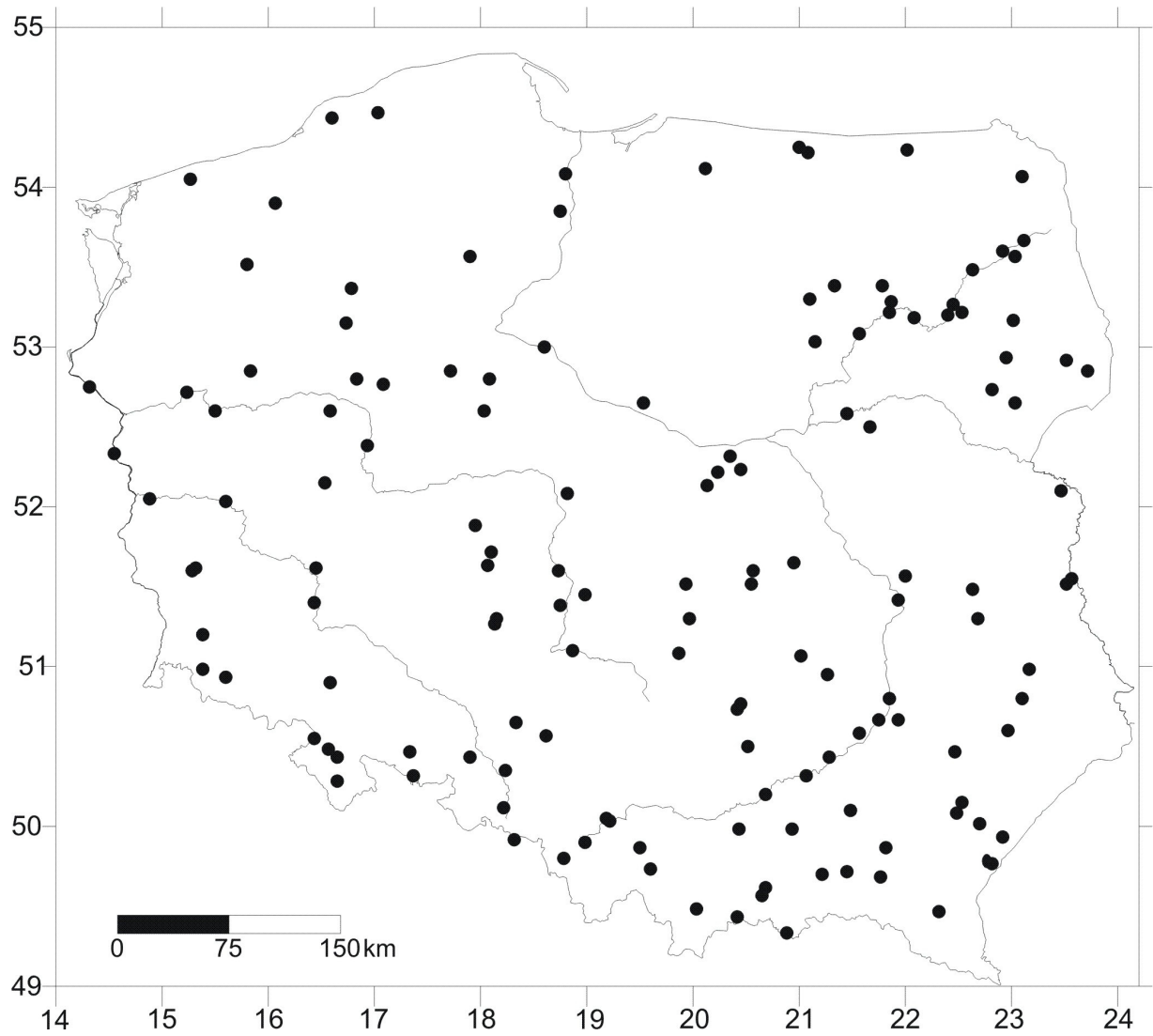

Ryc. 1. Położenie profili rzecznych

Fig. 1. Location of profiles on the rivers 
Obliczono także miesięczne, sezonowe i roczne zmiany odpływu w latach o wysokich indeksach $\mathrm{NAO}_{\text {DJFM }} \mathrm{w}$ porównaniu $\mathrm{z}$ odpływem w latach o niskich wartościach indeksu $\mathrm{NAO}_{\mathrm{DJFM}}$. W celu określenia zmian wysokości odpływów rzek w obu fazach $\mathrm{NAO}_{\text {DJFM }}$ względem siebie zastosowano wskaźnik zmian:

$$
S_{\bar{X}_{\mathrm{NAO+}+} \bar{X}_{\mathrm{NAO}-}}=\frac{\bar{X}_{\mathrm{NAO+}}}{\bar{X}_{\mathrm{NAO-}}} \cdot 100 \%
$$

gdzie $\bar{X}_{\mathrm{NAO+}}, \bar{X}_{\mathrm{NAO}-}-$ średnie wysokości odpływów w pozytywnej $(\mathrm{NAO+})$ lub negatywnej $(N A O-)$ fazie $\mathrm{NAO}_{\mathrm{DJFM}}$.

Obliczony wskaźnik wyraża procentową wysokość odpływu w pozytywnej fazie $\mathrm{NAO}_{\text {DJFM }}$, przy założeniu że jego wysokość w negatywnej fazie $\mathrm{NAO}_{\text {DJFM }}$ wynosi $100 \%$.

Przy realizacji strony graficznej skorzystano z programów: Surfer 8 [Golden Software], CorelDRAW 12 [Corel], a przy konstrukcji map izoliniowych wykorzystano procedurę krigingu.

\section{WYNIKI BADAŃ}

Wyniki przeprowadzonych badań wskazują na wyraźnie odmienne warunki kształtowania się odpływu rzek w Polsce, a także jego wysokość i zmiany w cyklu rocznym w różnych fazach Oscylacji Północnoatlantyckiej. Obserwowane różnice odpływów miesięcznych i sezonowych w różnych fazach $\mathrm{NAO}_{\mathrm{DJFM}}$ i ich statystyczna istotność wykazują wyraźne czasowe zróżnicowanie (ryc. 2). W miesiącach zimowych (I, II i sezon zimowy) znacznie wyższe odpływy obserwuje się w pozytywnej fazie NAO (NAO+) w przypadku ponad $80 \%$ serii odpływów, przy czym aż 30\% wykazuje różnice statystycznie istotne. W marcu, ze względu na zróżnicowany na obszarze Polski termin początku roztopów, dochodzi do zmiany i ilość analizowanych serii, w których wyższe odpływy obserwuje się w pozytywnej i negatywnej fazie NAO, są podobne. Wśród dodatnich różnic (wyższe odpływy w pozytywnej fazie NAO) ponad 10\% stanowią różnice statystycznie istotne, a wśród różnic negatywnych - poniżej 5\%. W pozostałych miesiącach, a także sezonach na polskich rzekach obserwuje się zazwyczaj wyższe odpływy w negatywnej fazie NAO (różnice ujemne). Najliczniej, bo w ponad $90 \%$ analizowanych serii, w przypadku odpływów w kwietniu i maju. W miesiącach tych różnice odpływów w największym odsetku profili rzecznych (25\%) są też statystycznie istotne.

Zróżnicowane warunki klimatyczne w Polsce wpływają także na kształtowanie się i wysokość odpływu w różnych fazach NAO. Potwierdzają to mapy 


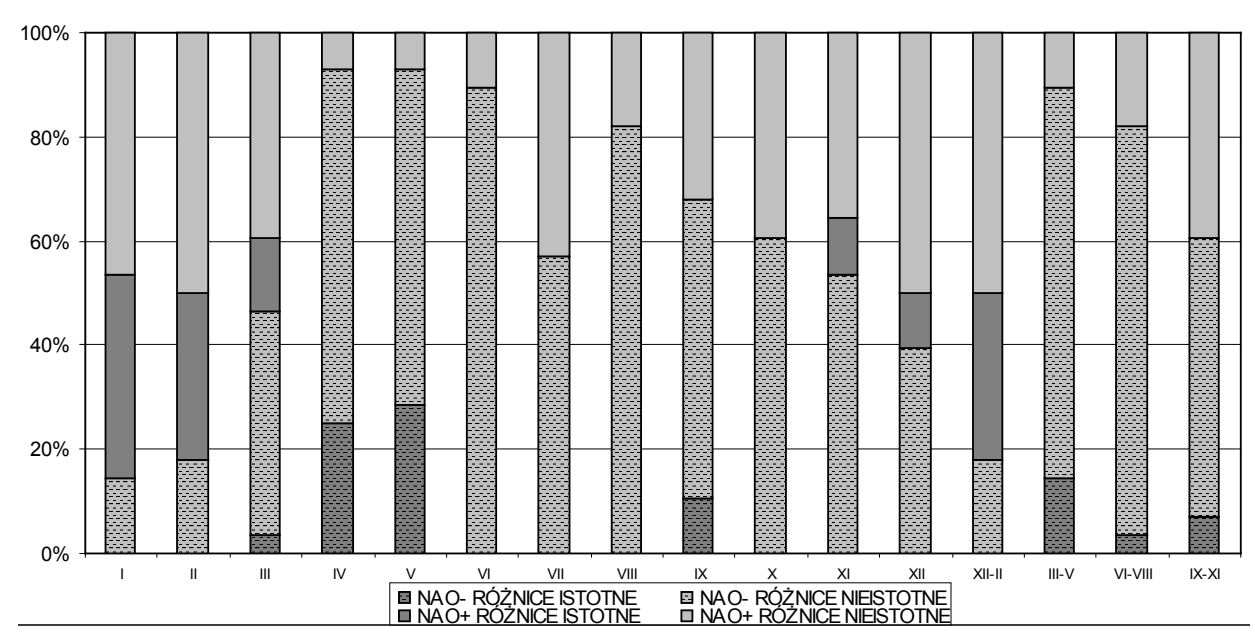

Ryc. 2. Procentowy udział istotnych statystycznie różnic odpływu w różnych fazach $\mathrm{NAO}_{\mathrm{DJFM}}$

Fig. 2. The percentage share of the statistically significant differences in different $\mathrm{NAO}_{\text {DJFM }}$ stages

przedstawiające zarówno czasowe, jak i przestrzenne zróżnicowanie wysokości odpływów w cyklu rocznym. W styczniu i lutym na rzekach większości obszaru Polski odnotowuje się wyższe odpływy w pozytywnej fazie NAO. Odchylenia wysokości odpływów obserwowanych w tej fazie NAO od odpływów w fazie NAO- wyraźnie wzrastają z południowego zachodu na północny wschód kraju. Odpływ rzek w północno-wschodniej części kraju w pozytywnej fazie NAO jest na niektórych rzekach nawet trzykrotnie wyższy od obserwowanego w negatywnej fazie NAO (ryc. 3). Na rzekach tego obszaru obserwuje się też najbardziej istotne statystycznie (nawet $p<0,01$ ) różnice między odpływem w latach o dodatnim $\left(\mathrm{NAO}+\right.$ ) i ujemnym (NAO-) indeksie $\mathrm{NAO}_{\text {DJFM }}$ (ryc. 4). $\mathrm{W}$ analizowanych miesiącach duże różnice odpływów między okresami o skrajnych wartościach indeksu $\mathrm{NAO}_{\text {DJFM }}$ występują również w przypadku rzek górskich i Pojezierza Pomorskiego. W styczniu na niektórych rzekach są one istotne statystycznie $(p<0,05)$, a odpływ w fazie NAO+ jest wyższy o $25 \%-50 \%$ od odpływu w fazie NAO-.

W marcu sytuacja zmienia się. W Polsce północnej i w górach nadal przeważa odpływ w fazie $\mathrm{NAO}+$, jednak istotnie statystyczne różnice występują już tylko w północno-wschodniej części kraju $(p<0,01)$. Tam też odpływ rzek w fazie NAO+ stanowi ponad $175 \%$ odpływu w fazie NAO-. Na rzekach centralnej, nizinnej, a także wyżynnej część kraju występuje wyższy odpływ w negatywnej fazie NAO, lokalnie o $25 \%$. Jednak obserwowane różnice są zazwyczaj nieistotne statystycznie (ryc. 5 i 6). 

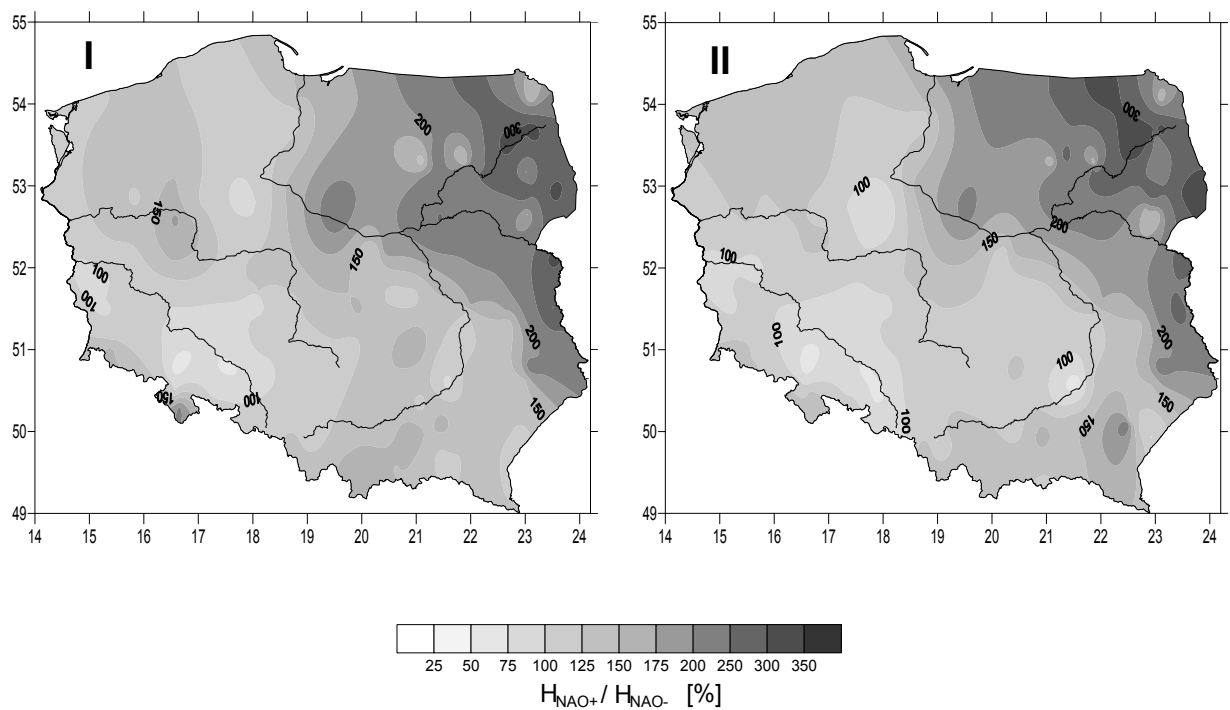

Ryc. 3. Zmiany miesięcznych (I, II) odpływów w pozytywnej fazie w stosunku do fazy negatywnej $\mathrm{NAO}_{\mathrm{DJFM}}$

Fig. 3. Changes of monthly (I, II) flows in a positive $\mathrm{NAO}_{\text {DJFM }}$ stage with regard to a negative $\mathrm{NAO}_{\text {DJFM }}$ stage
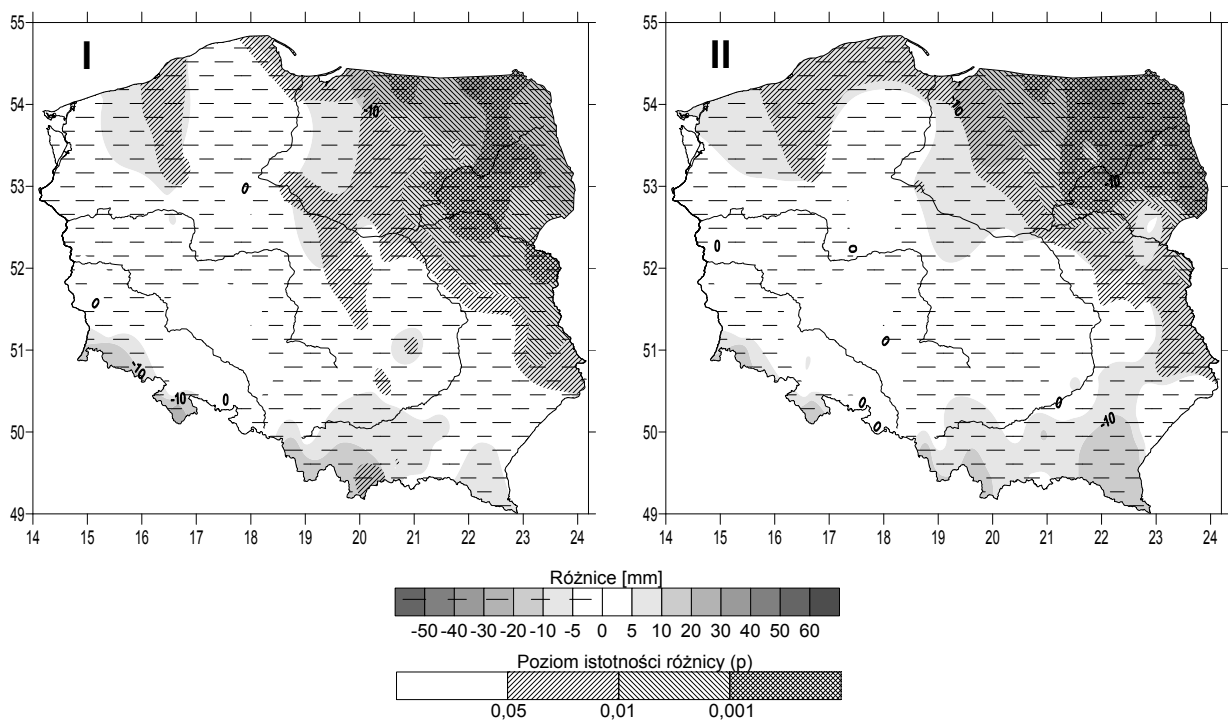

Ryc. 4. Różnice miesięcznych odpływów (I, II) w mm i ich statystyczna istotność ( $p$ ) między pozytywną i negatywną fazą $\mathrm{NAO}_{\text {DJFM }}$

Fig. 4. Differences in monthly flows (I, II) between a positive and a negative NAO stage ( $p-$ level of significance of the difference) 

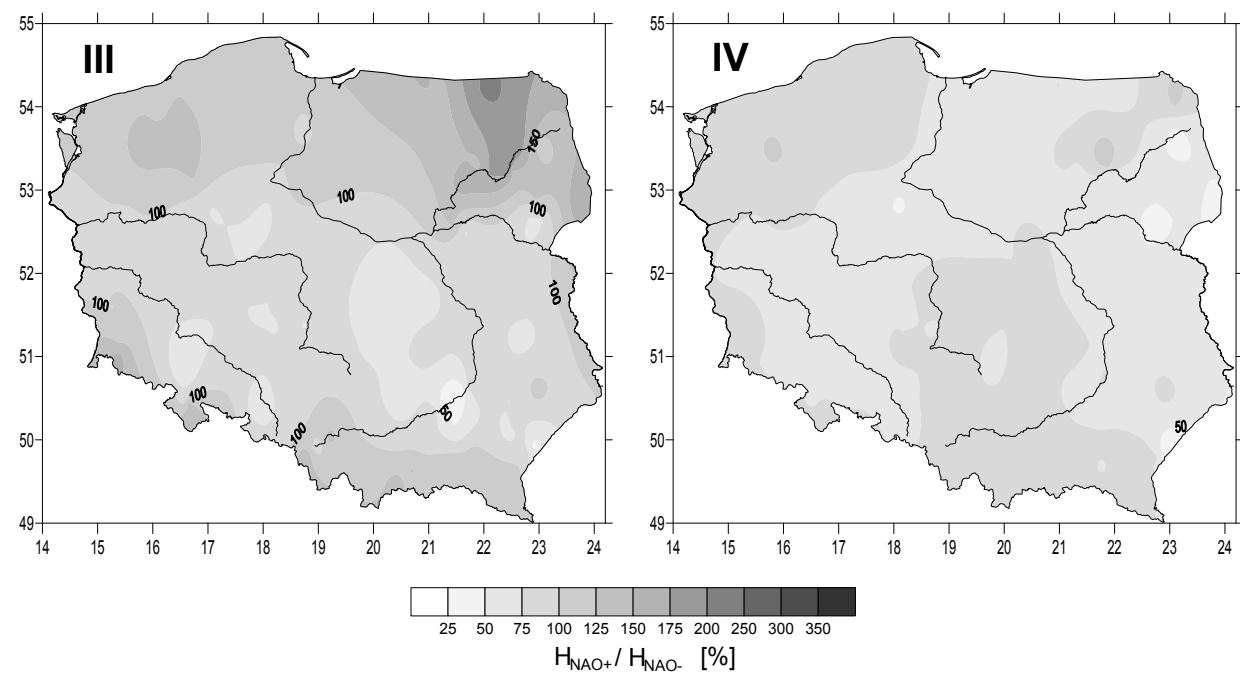

Ryc. 5. Zmiany miesięcznych (III, IV) odpływów w pozytywnej fazie w stosunku do fazy negatywnej $\mathrm{NAO}_{\mathrm{DJFM}}$

Fig. 5. Changes of monthly flows (III, IV) in a positive $\mathrm{NAO}_{\mathrm{DJFM}}$ stage with regard to a negative $\mathrm{NAO}_{\text {DJFM }}$ stage
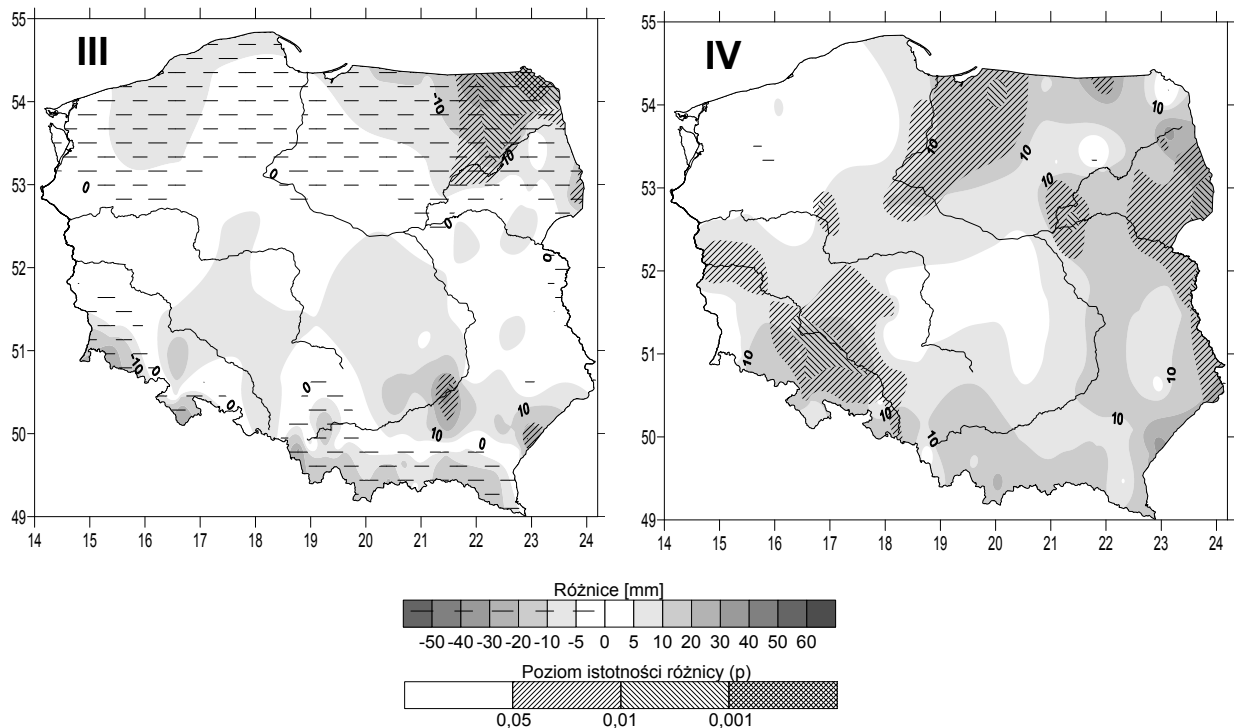

Ryc. 6. Różnice miesięcznych odpływów (III, IV) w mm i ich statystyczna istotność ( $p$ ) między pozytywną i negatywną fazą $\mathrm{NAO}_{\mathrm{DJFM}}$

Fig. 6. Differences in monthly flows (III, IV) between a positive and a negative NAO stage ( $p-$ level of significance of the difference) 
W kwietniu już w całej Polsce na rzekach wyraźnie wyższe odpływy występują w latach o ujemnych wartościach indeksu NAO $_{\text {DJFM. }}$ Odpływ w negatywnej fazie jest wyższy od obserwowanego w fazie pozytywnej o 25\% na rzekach górnej i środkowej części dorzecza Odry, środkowej części dorzecza Warty, zachodniej części Pojezierza Mazurskiego oraz rzekach wschodniej części dorzecza Wisły poniżej ujścia Sanu, gdzie lokalnie jest wyższy nawet o ponad 50\%. $\mathrm{Na}$ rzekach tych regionów odnotowuje się też najbardziej istotne statystycznie $(p<0,05)$ różnice odpływów w różnych fazach $\mathrm{NAO}_{\mathrm{DJFM}}$ (ryc. 5 i 6).

Podobna sytuacja ma miejsce w maju, przy czym wyraźna dominacja odpływów w negatywnej fazie $\mathrm{NAO}_{\text {DJFM }}$ obserwowana jest na rzekach centralnej i zachodniej części kraju. Odpływy są wtedy wyższe o ponad 25\%, a lokalnie nawet o 50\% niż w fazie NAO+. Rozszerza się też obszar istotnych statystycznie różnic odpływów ( $p<0,05)$, obejmując większą część tego obszaru, z wyjątkiem centralnej części Pojezierza Pomorskiego i zlewni rzek między Wartą i Wisłą. Przewaga odpływu w negatywnej fazie NAO zmniejsza się we wschodniej części kraju, a na południowym wschodzie, od Popradu po San, wyższe odpływy występują w pozytywnej fazie $\mathrm{NAO}_{\text {DJFM. }}$. Jednak obserwowane różnice odpływów nie są istotne statystycznie (ryc. 7 i 8). W czerwcu na większości rzek nadal przeważa odpływ w negatywnej fazie $\mathrm{NAO}_{\mathrm{DJFM}}$, jednak istotne statystycznie różnice są tylko na niektórych rzekach górnej części dorzecza Warty i Noteci. Na rzekach pojeziernych oraz górnej części systemu Wisłoki nieznacznie wyższe odpływy występują w pozytywnej fazie $\mathrm{NAO}_{\text {DJFM }}$ (ryc. 7 i 8). Podobna sytuacja ma miejsce również w kolejnych miesiącach (VII-IX) - nadal wyższe odpływy obserwuje się w negatywnej fazie $\mathrm{NAO}_{\text {DJFM }}$, jednak coraz większy obszar na wschodzie kraju charakteryzuje się wyższymi odpływami w fazie pozytywnej. Nie odnotowuje się też istotnych statystycznie różnic między odpływami w różnych fazach $\mathrm{NAO}_{\mathrm{DJFM}}$. Od listopada na coraz większym obszarze kraju, w jego północnej i wschodniej części, a w grudniu także w zlewniach sudeckich i Beskidu Śląskiego, mamy wyższy odpływ w pozytywnej fazie NAO $_{\text {DJFM }}$. $\mathrm{W}$ okresie tym istotne statystycznie różnice $(p<0,05)$ odpływów w różnych fazach $\mathrm{NAO}_{\text {DJFM }}$ występują jedynie na rzekach w dorzeczu Biebrzy.

Prawidłowości dotyczące przestrzennego zróżnicowania miesięcznych odpływów rzek w Polsce w odmiennych fazach $\mathrm{NAO}_{\text {DJFM }}$ znajdują potwierdzenie także w przypadku analizy odpływów sezonowych. Zimą (średni odpływ z miesięcy XII-II) zdecydowanie wyższe odpływy obserwuje się na większości polskich rzek w pozytywnej fazie $\mathrm{NAO}_{\mathrm{DJFM}}$. W północno-wschodniej części kraju są one wówczas 2-3-krotnie wyższe niż w fazie NAO-, a obserwowane różnice bardzo istotne statystycznie $(p<0,001)$ - rycina 9 i 10 . Jedynie niektóre rzeki górnej i środkowej części dorzecza Odry oraz górnej części dorzecza Noteci wykazują wyższe odpływy w negatywnej fazie $\mathrm{NAO}_{\mathrm{DJFM}}$. Jednak różnice odpływów są niewielkie i nieistotne statystycznie.

Odpływy wiosenne i letnie na większości polskich rzek osiągają wyższe 


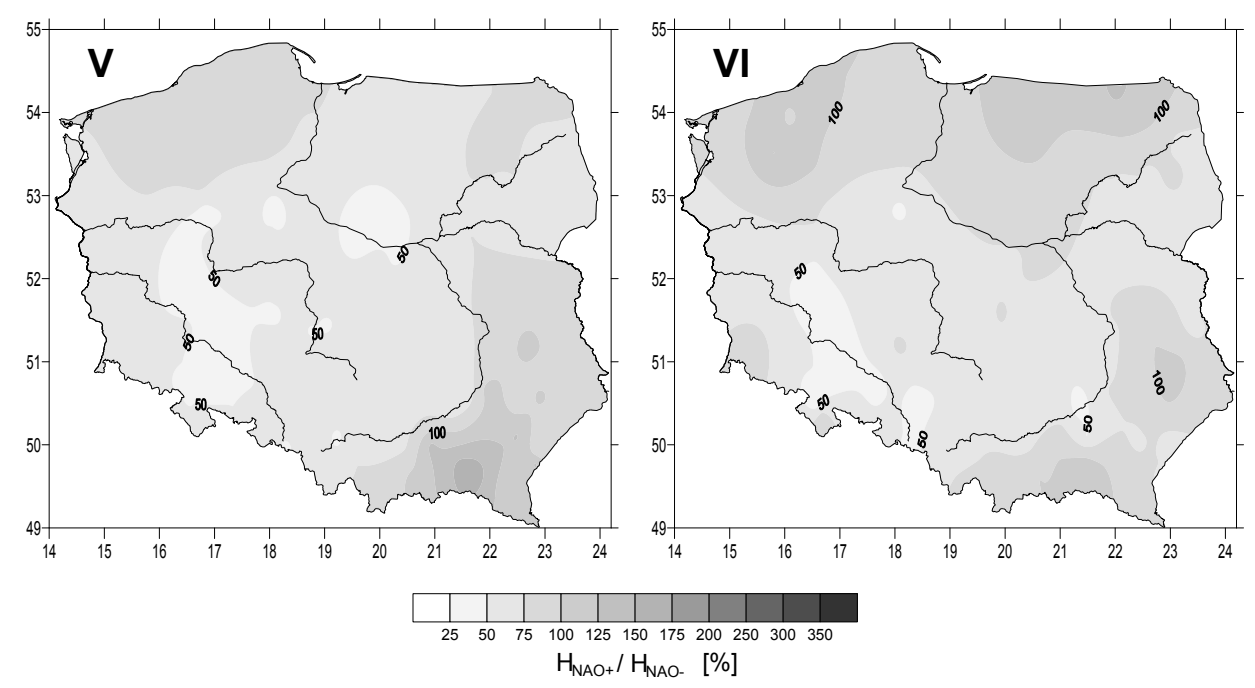

Ryc. 7. Zmiany odpływów miesięcznych (V, VI) w pozytywnej fazie w stosunku do fazy negatywnej $\mathrm{NAO}_{\text {DJFM }}$

Fig. 7. Changes of monthly flows $(\mathrm{V}, \mathrm{VI})$ in a positive $\mathrm{NAO}_{\mathrm{DJFM}}$ stage with regard to a negative $\mathrm{NAO}_{\text {DJFM }}$ stage
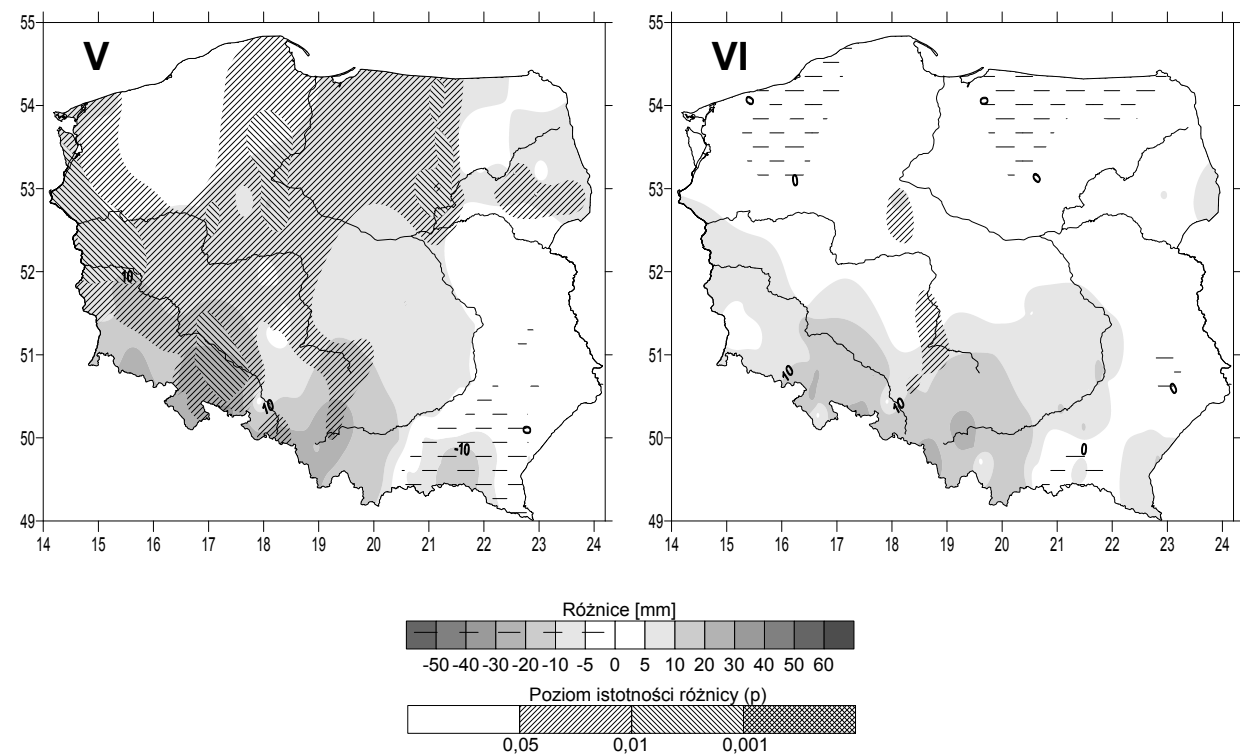

Ryc. 8. Różnice miesięcznych odpływów (V, VI) w mm i ich statystyczna istotność ( $p$ ) między pozytywną i negatywną fazą $\mathrm{NAO}_{\text {DJFM }}$

Fig. 8. Differences in monthly flows (V, VI) between a positive and a negative NAO stage ( $p-$ level of significance of the difference) 

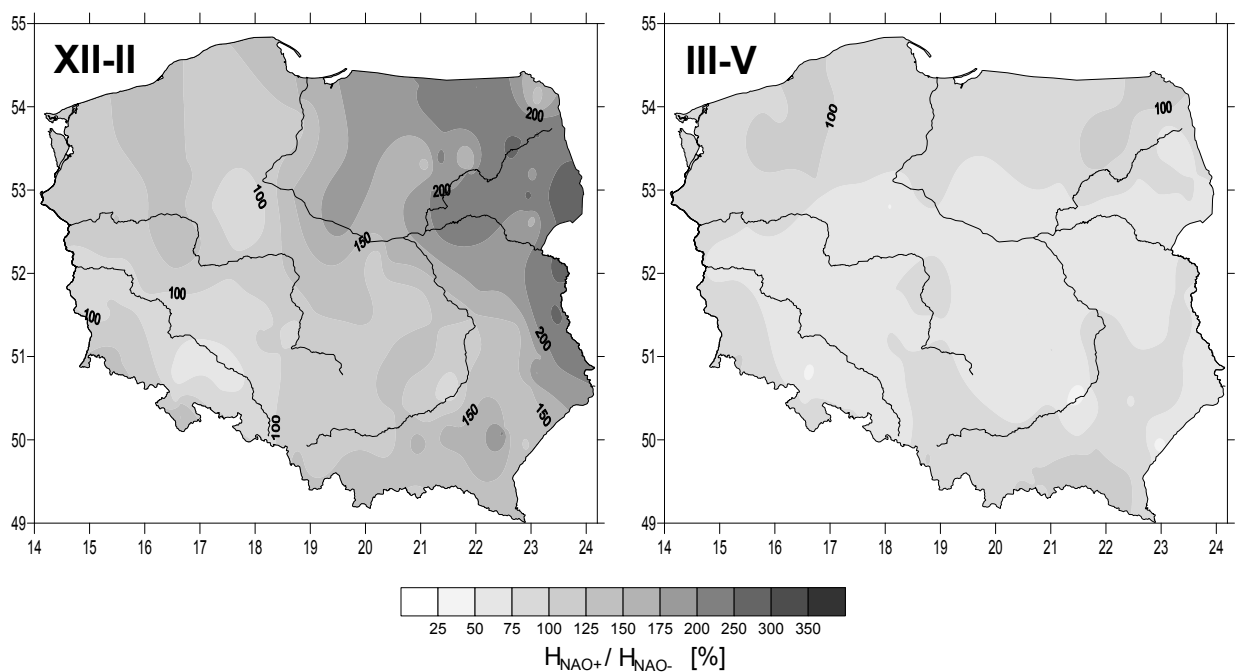

Ryc. 9. Zmiany odpływów sezonowych (XII-II, III-V) w pozytywnej fazie w stosunku do fazy negatywnej $\mathrm{NAO}_{\mathrm{DJFM}}$

Fig. 9. Changes of seasonal flows (XII-II, III-V) in a positive $\mathrm{NAO}_{\mathrm{DJFM}}$ stage with regard to a negative $\mathrm{NAO}_{\text {DJFM }}$ stage
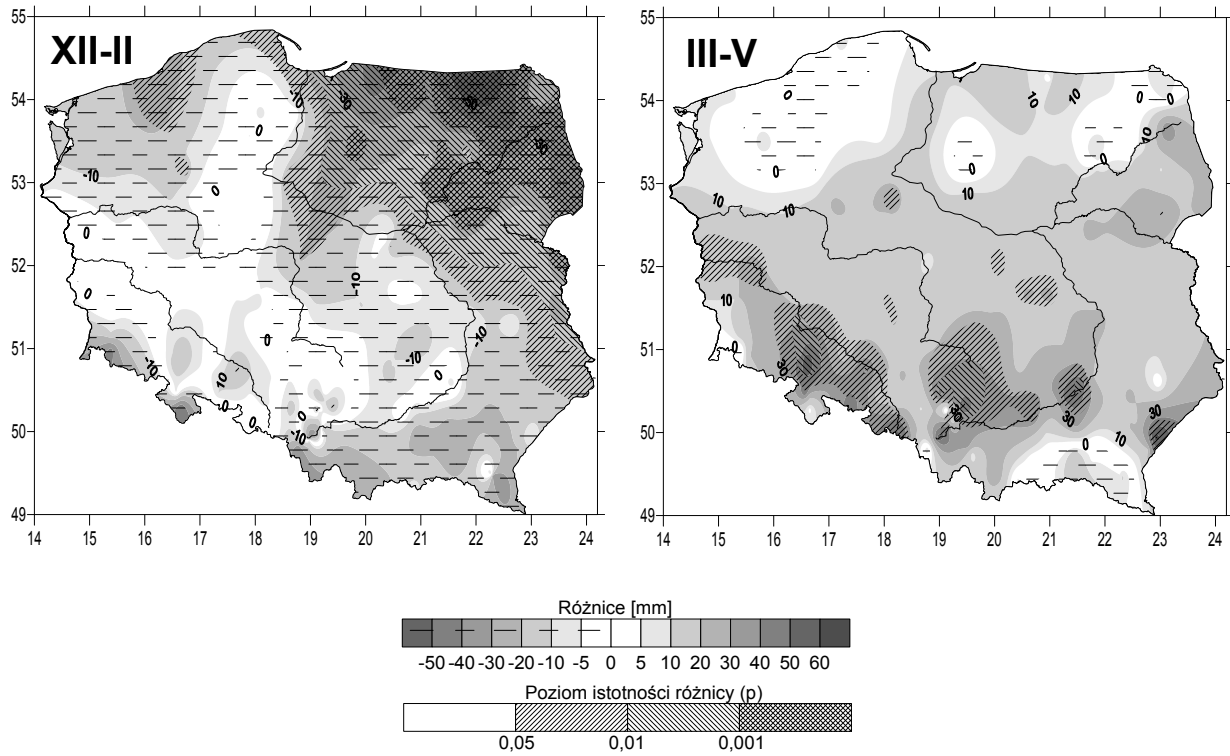

Ryc. 10. Różnice sezonowych odpływów (XII-II, III-V) w mm i ich statystyczna istotność ( $p$ ) między pozytywną i negatywną fazą $\mathrm{NAO}_{\text {DJFM }}$

Fig. 10. Differences in seasonal flows (XII-II, III-V) between a positive and a negative NAO stage ( $p$ - level of significance of the difference) 
wartości $\mathrm{w}$ negatywnej fazie $\mathrm{NAO}_{\mathrm{DJFM}}$. Odpływy obserwowane $\mathrm{w}$ tej fazie przewyższają odpływy fazy pozytywnej, szczególnie w centralnej części kraju, o 25-50\% - rycina 9 i 11. Istotne statystycznie różnice $(p<0,05)$ dotyczą jednak tylko niektórych rzek górnej i środkowej części dorzecza Odry. Jedynie pojedyncze rzeki pojezierne w tych sezonach wykazują przewagę odpływu w pozytywnej fazie $\mathrm{NAO}_{\mathrm{DJFM}}$. Jednak obserwowane różnice nie są istotne statystycznie (ryc. 10 i 12).

Jesienią (IX-XI) zdecydowanie powiększa się obszar kraju, głównie na wschód od Wisły i środkowa część Pojezierza Pomorskiego, na którym rzeki

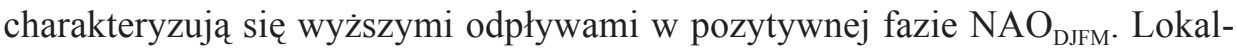
nie, w północno-wschodniej części kraju, odpływy rzek mogą być wówczas wyższe nawet o $50 \%$ od odpływów w fazie negatywnej, jednak obserwowane różnice nie są statystycznie istotne. Na pozostałym terenie odpływy rzek w fazie negatywnej nadal przewyższają te $\mathrm{z}$ fazy pozytywnej, jednak obserwowane różnice również nie są statystycznie istotne (ryc. 11 i 12).

Wpływ zmian natężenia Oscylacji Północnoatlantyckiej w sezonie zimowym na odpływ rzek w Polsce jest zróżnicowany przestrzennie i modyfikuje jego sezonowy rozkład, co potwierdza analiza przestrzenna zmian odpływu w poszczególnych miesiącach i porach roku. Analiza zmian odpływów rocznych wskazuje jednak na brak istotnych statystycznie różnic w ich wysokościach w odmiennych fazach $\mathrm{NAO}_{\mathrm{DJFM}}$. Zauważalne jednak jest dość charakterystyczne przestrzenne zróżnicowanie wpływu zmian natężenia $\mathrm{NAO}_{\text {DJFM }}$. Wyższe o około $25 \%$ odpływy w pozytywnej fazie $\mathrm{NAO}_{\text {DJFM }}$ obserwuje się na rzekach pojeziernych i we wschodniej części kraju. Na pozostałym obszarze rzeki charakteryzują się wyższymi do $25 \%$ odpływami w negatywnej fazie $\mathrm{NAO}_{\text {DJFM }}$. Jedynie odplyw rzek w górnej części dorzecza Odry wykazuje wyższe wartości nawet o 50\%, a obliczone różnice odpływów są na granicy istotności statystycznej (ryc. 13 i 14).

\section{PODSUMOWANIE}

Wyniki badań potwierdziły silny wpływ Oscylacji Północnoatlantyckiej na wysokość i sezonowość odpływu rzek polskich. Zmiany odpływów w analizowanych fazach $\mathrm{NAO}_{\text {DJFM }}$, ich różnice i statystyczna istotność wskazują na duże zarówno czasowe, jak i przestrzenne zróżnicowanie. Silny wpływ zmian natężenia Oscylacji Północnoatlantyckiej w sezonie zimowym na odpływ rzek obserwuje się głównie w północno-wschodniej i północnej części kraju. Odpływy rzek tych regionów w dodatniej fazie $\mathrm{NAO}_{\text {DJFM }} \mathrm{są} \mathrm{w} \mathrm{miesiącach} \mathrm{zimowych} \mathrm{dwu-}$ krotnie, a nawet ponad trzykrotnie wyższe niż w fazie ujemnej, a obliczone różnice są istotne statystycznie. W miesiącach wiosennych odpływ rzek północnowschodniej Polski oraz rzek środkowej części dorzecza Odry i Warty, a w maju prawie całego kraju jest o ponad 50\% wyższy w fazie ujemnej. W pozostałych 

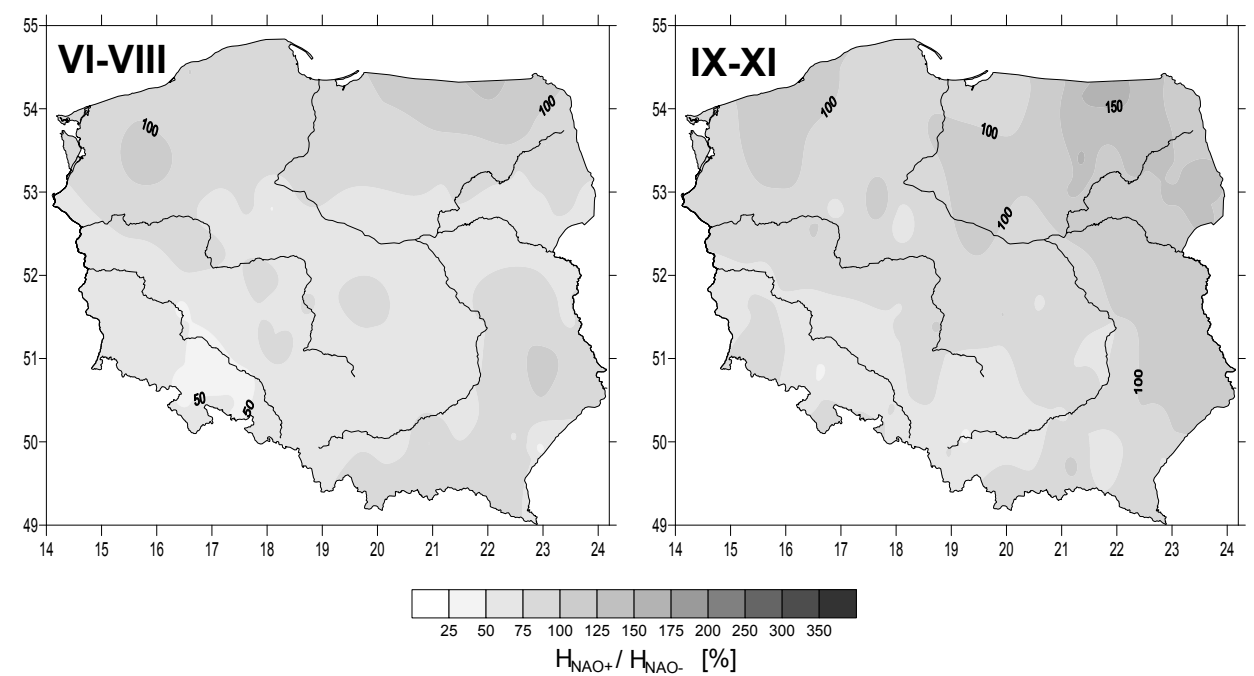

Ryc. 11. Zmiany odpływów sezonowych (VI-VIII, IX-XI) w pozytywnej fazie w stosunku do fazy negatywnej $\mathrm{NAO}_{\mathrm{DJFM}}$

Fig. 11. Changes of seasonal flows (VI-VIII, IX-XI) in a positive $\mathrm{NAO}_{\mathrm{DJFM}}$ stage with regard to a negative $\mathrm{NAO}_{\text {DJFM }}$ stage
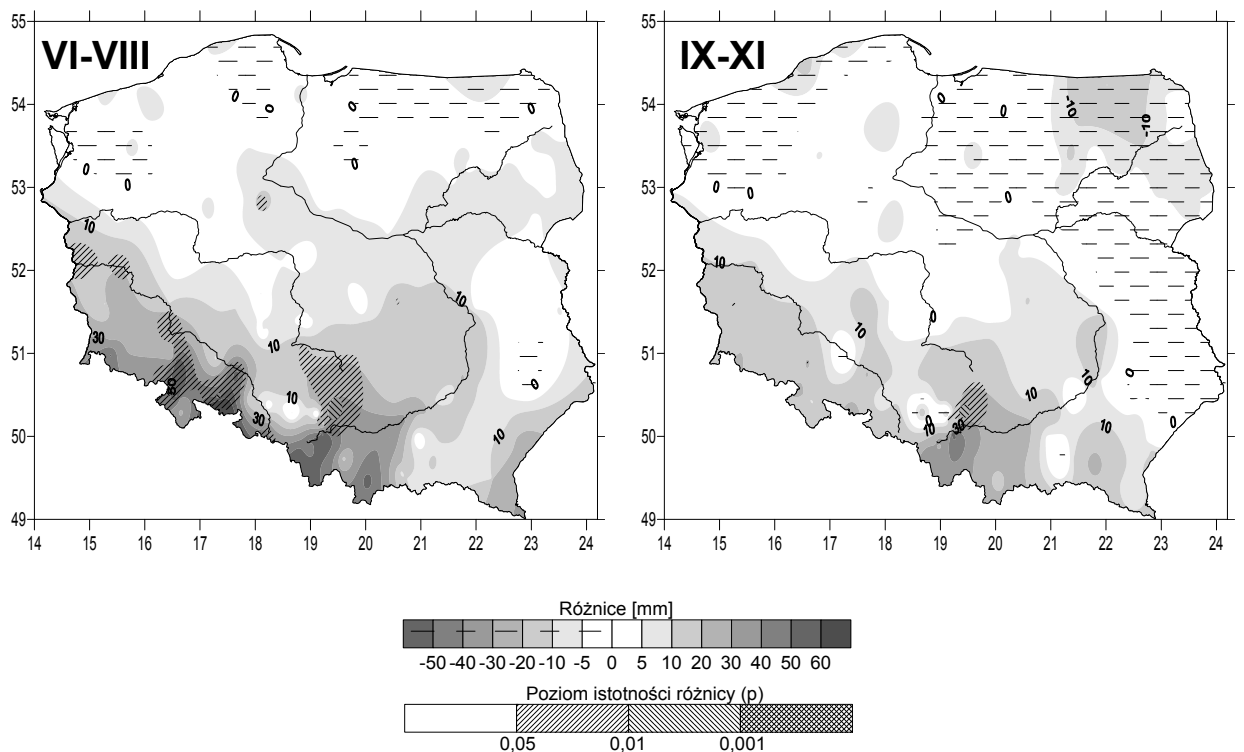

Ryc. 12. Różnice sezonowych odpływów (VI-VIII, IX-XI) w mm i ich statystyczna istotność $(p)$ między pozytywną i negatywną fazą $\mathrm{NAO}_{\text {DJFM }}$

Fig. 12. Differences in seasonal flows (VI-VIII, IX-XI) between a positive and a negative NAO stage ( $p$ - level of significance of the difference) 


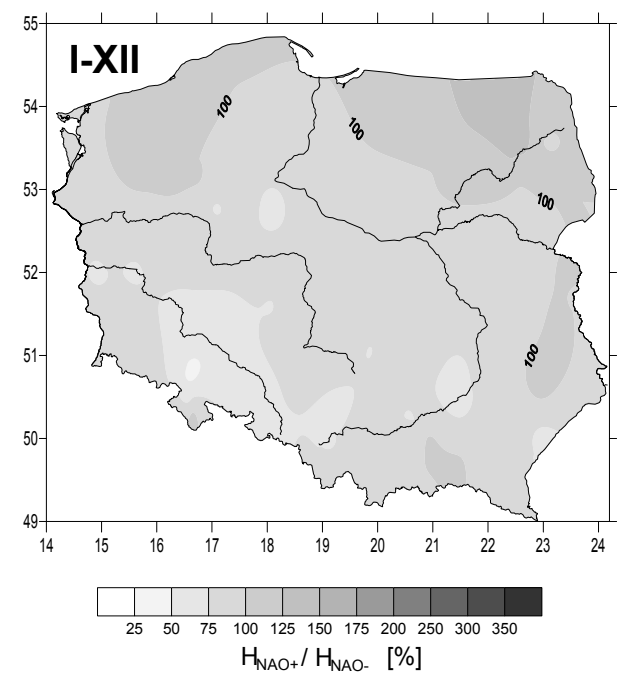

Ryc. 13. Zmiany rocznych odpływów w pozytywnej fazie w stosunku do fazy negatywnej $\mathrm{NAO}_{\mathrm{DJFM}}$

Fig. 13. Changes of annual flows in a positive $\mathrm{NAO}_{\text {DJFM }}$ stage with regard to a negative $\mathrm{NAO}_{\text {DJFM }}$ stage

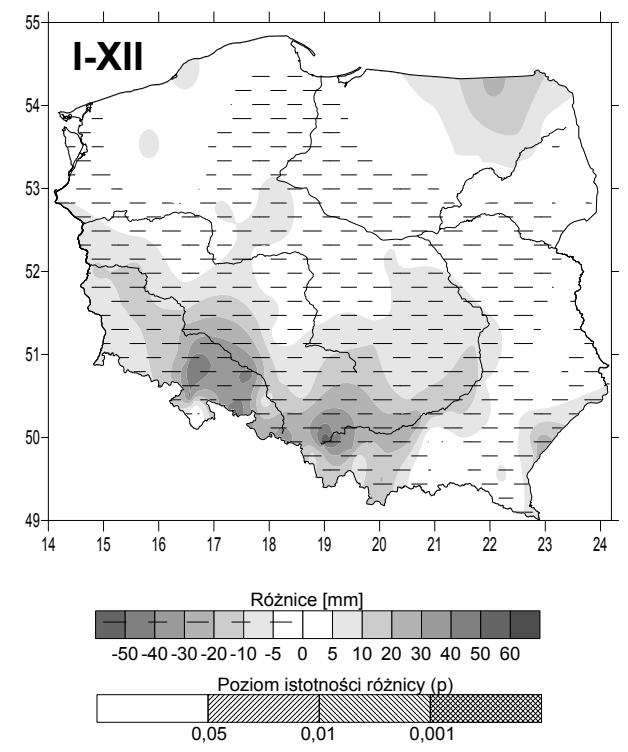

Ryc. 14. Różnice rocznych odpływów w mm $\mathrm{i}$ ich statystyczna istotność $(p)$ między pozytywną i negatywną fazą $\mathrm{NAO}_{\text {DJFM }}$

Fig. 14. Differences in annual flows (I, II) between a positive and a negative NAO stage ( $p$ - level of significance of the difference)

miesiącach na większości analizowanych rzek zazwyczaj nie obserwuje się istotnych statystycznie różnic w odpływach między odmiennymi fazami $\mathrm{NAO}_{\mathrm{DJFM}}$.

Zatem najsilniejszy wpływ Oscylacji Północnoatlantyckiej na odpływy rzek obserwuje się w miesiącach zimowo-wiosennych, a więc, gdy w Polsce kształtują się największe zasoby wodne. W pozytywnej fazie NAO, w miesiącach zimowych należy spodziewać się znacznego zwiększenia odpływu głównie na rzekach północno-wschodniej części kraju oraz wyraźnego zmniejszenia odpływów rzek na prawie całym terytorium kraju w okresie wiosennym. Zróżnicowanie warunków środowiskowych zlewni analizowanych rzek, a także uwarunkowania klimatyczne formowania odpływu sprawiają, że obserwowane zależności mają jednak różny charakter i siłę. Potwierdziła czasowa i przestrzenna analiza zmian wysokości odpływów w różnych fazach Oscylacji Północnoatlantyckiej. Za region, w którym na rzekach obserwuje się największe zmiany wysokości odpływów w zależności od natężenia NAO, należy uznać dorzecze Narwi, a największe różnice odpływów rzek przypadają na miesiące zimowe i wiosenne. 


\section{LITERATURA}

Bednorz E., 2009: Wpływ sytuacji barycznych na występowanie pokrywy śnieżnej na obszarach nizinnych środkowej Europy. Wyd. Nauk. UAM Poznań, 129 s.

Bryś K., Bryś T., 2002: Wpływ Oscylacji Pótnocnoatlantyckiej na zmienność warunków wilgotnościowych, radiacyjnych, dynamicznych $i$ ewaporacyjnych we Wrocławiu-Swojcu w latach 1946-2000. [W:] Oscylacja Pótnocnego Atlantyku i jej rola w ksztattowaniu zmienności warunków klimatycznych i hydrologicznych Polski, Akad. Morska w Gdyni, 147-160.

Falarz M., 2007: Snow cover variability in Poland in relation to the macro- and mesoscale atmospheric circulation in the twentieth century. Internat. Journ. of Climatol., 27, 2069-2081.

Hurrell J.W., 1995: Decadal trends in the North Atlantic Oscillation and relationship to regional temperature and precipitation. Sci., 269, 676-679.

Kaczmarek Z., 2002: Wplyw Oscylacji Pólnocnoatlantyckiej na przepływy rzek europejskich. [W:] A. Marsz, A. Styszyńska (red.), Oscylacja Pótnocnego Atlantyku i jej rola w kształtowaniu zmienności warunków klimatycznych i hydrologicznych Polski. Akad. Morska w Gdyni, 163172.

Kaczmarek Z., 2003: The Impact Climate Variability on Flood Risk in Poland. Risk Analysis, 23, $559-566$.

Kożuchowski K., Degirmendžić J., 2002: Wskaźniki cyrkulacji a temperatura powietrza w Polsce. [W:] A. Marsz, A. Styszyńska (red.), Oscylacja Pótnocnego Atlantyku i jej rola w kształtowaniu zmienności warunków klimatycznych i hydrologicznych Polski. Akad. Morska w Gdyni, $111-128$.

Limanówka D., Nieckarz Z., Pociask-Karteczka J., 2002: The North Atlantic Oscillation impast on hydrological regime in Polish Carpathians. [W:] Interdisciplinary Approaches in Small Catchment Hydrology: Monitoring and Research. FRIEND International Conference, Demanovska Dolina, 132-135.

Marsz A., 1999: Oscylacja Pótnocnoatlantycka a reżim termiczny zim na obszarze pótnocno-zachodniej Polski i polskim wybrzeżu Battyku. Przegl. Geogr., 71, 3, 225-245.

Marsz A., 2001: Stan termiczny Pótnocnego Atlantyku a reżim termiczny zim na polskim wybrzeżu Bałtyku (problem dlugoterminowej prognozy termiki zim). Wyższa Szkoła Morska w Gdyni, 107 ss.

Marsz A., Styszyńska A., 2001: Oscylacja Pótnocnego Atlantyku a temperatura powietrza nad Polska. Wyższa Szkoła Morska w Gdyni, $101 \mathrm{s.}$

Marsz A., Żmudzka E., 1999: Oscylacja Pótnocnego Atlantyku a dtugość okresu wegetacyjnego $w$ Polsce. Przegl. Geofiz., 44, 4, 199-210.

Niedźwiedź T., 2002: Relacje między NAO a wskaźnikami cyrkulacji nad Polskq. [W:] A. Marsz, A. Styszyńska (red.), Oscylacja Pótnocnego Atlantyku i jej rola w ksztaltowaniu zmienności warunków klimatycznych i hydrologicznych Polski. Akad. Morska w Gdyni, 87-97.

Pociask-Karteczka J., Limanówka D., Nieckarz Z., 2002-2003: Wpływ oscylacji pótnocnoatlantyckiej na przepływy rzek karpackich (1951-2000). Fol. Geograph., Ser. Geographica-Physica, 33-34, 89-104.

Przybylak R., Wójcik G., Marciniak K., 2003: Wpływ Oscylacji Pótnocnoatlantyckiej i Arktycznej na warunki termiczne chłodnej pory roku w Polsce w XVI-XX wiekach. Przegl. Geofiz., 48, $61-74$.

Styszyńska A., 2001: Oscylacja Pótnocnego Atlantyku a opady na obszarze Polski. Pr. i Stud. Geogr., 29, 232-241.

Styszyńska A., Tamulewicz J., 2004: Warta river discharges in Poznań and atmospheric circulation in the North Atlantic region. Quaes. Geograph., 23, 63-81.

Wibig J., 2001: Wptyw cyrkulacji atmosferycznej na rozktad przestrzenny anomalii temperatury i opadów w Europie. Wyd. Uniw. Łódzkiego, 208 s.

Wrzesiński D., 2004: Flow regimes of rivers of northern and central Europe in various circula- 
tion periods of the North Atlantic Oscillation (NAO). XXIII Nordic Hydrological Conference, NHP Report 48, Tallinn, 670-679.

Wrzesiński D., 2005: Changes of the hydrological regime of rivers of northern and central Europe in various circulation periods of the North Atlantic Oscillation. Quaes. Geograph., 24, 97-109.

Wrzesiński D., 2007: Impact of the North Atlantic Oscillation on features of the hydrological regimes in Europe. Proceedings The Third International Conference on Climate and Water. Finnish Environment Institute SYKE, Helsinki, 538-543.

Wrzesiński D., 2008a: Impact of the North Atlantic Oscillation on river runoff in Poland. IWRA $13^{\text {th }}$ World Water Congress Montpellier, France, 1-4 September (http://wwc2008.msem. univ-montp2.fr/resource/authors/abs217_article.pdf).

Wrzesiński D., 2008b: Typology of spatial patterns seasonality in European rivers flow regime. Quaes. Geograph. 27A/1: 87-98.

Wrzesiński D., 2009: Stabilność reżimu odpływu rzek w Polsce. [W:] A. Jankowski, D. Absalon, R. Machowski, M. Ruman (red.), Przeobrażenia stosunków wodnych w warunkach zmieniajacego się środowiska. Sosnowiec, 307-318. 